\title{
COMPARISON OF FOOT MORPHOLOGY BETWEEN CHINESE AND MONGOLIAN CHILDREN
}

\author{
Shiya RAN ${ }^{1}$, Hao LIU ${ }^{2}$, Shiyang YAN ${ }^{1,2}$, Ruoyi LI ${ }^{1,2}$, Jitka BADUROVA ${ }^{3}$, Luming YANG ${ }^{1,2^{*}}$ \\ ${ }^{1}$ National Engineering Laboratory for Clean Technology Leather Manufacture, Sichuan University, Chengdu 610065, China \\ ${ }^{2}$ Key Laboratory of Leather Chemistry and Engineering, Ministry of Education, Sichuan University, Chengdu 610065, China \\ ${ }^{3}$ Tomas Bata University, Zlin, 76001, Czech Republic
}

Received: 16.01.2020

Accepted: 03.04.2020

https://doi.org/10.24264/Ifj.20.2.1

\section{COMPARISON OF FOOT MORPHOLOGY BETWEEN CHINESE AND MONGOLIAN CHILDREN}

ABSTRACT. Knowledge of foot morphology is fundamental to optimize children's footwear design. The aim of this study is to compare the foot morphology of Chinese and Mongolian children from 7 to 14 years old. Relative data of 339 Mongolian children and another matched 379 Chinese children were collected using 3D foot scanner. The findings of this study are as follows: i) the absolute foot length of Chinese children is significantly greater than that of Mongolian children of the same age; ii) Mongolian children show significantly greater heel width, toe thickness, lateral malleolus height, instep height and ball girth compared to Chinese children of the same age. The foot width of Chinese children is significantly greater than that of Mongolian children of the same age; iii) Chinese children have a higher risk of hallux valgus than Mongolian children of both sexes. Small variations in foot morphology discussed in this paper could be useful when considering the shoes design for Mongolian and Chinese children.

KEY WORDS: foot morphology, Mongolian children, Chinese children, footwear design

\section{COMPARAREA MORFOLOGIEI PICIORULUI LA COPIII CHINEZI ȘI MONGOLI}

REZUMAT. Cunoașterea morfologiei piciorului este fundamentală pentru a optimiza proiectarea încălțămintei pentru copii. Scopul acestui studiu este de a compara morfologia piciorului la copiii chinezi și mongoli cu vârste între 7 și 14 ani. S-au colectat date de la 339 de copii mongoli și 379 de copii chinezi folosind un scaner 3D pentru picioare. Rezultatele acestui studiu sunt următoarele: i) lungimea absolută a piciorului la copiii chinezi este semnificativ mai mare decât în cazul copiilor mongoli de aceeași vârstă; ii) copiii mongoli prezintă lățimea călcâiului, grosimea degetelor, înălțimea maleolei exterioare, înălțimea căputei și circumferința zonei metatarsofalangiene semnificativ mai mari în comparație cu copiii chinezi de aceeași vârstă. Lățimea piciorului la copii chinezi este semnificativ mai mare decât în cazul copiilor mongoli de aceeași vârstă; iii) copiii chinezi au un risc mai mare de a dezvolta hallux valgus decât copiii mongoli de ambele sexe. Micile variații ale morfologiei picioarelor discutate în această lucrare ar putea fi utile la proiectarea încălțămintei pentru copiii mongoli și chinezi.

CUVINTE CHEIE: morfologia piciorului, copii mongoli, copii chinezi, proiectarea încălțămintei

\section{COMPARAISON DE LA MORPHOLOGIE DU PIED ENTRE LES ENFANTS CHINOIS ET MONGOLIENS}

RÉSUMÉ. La connaissance de la morphologie du pied est fondamentale pour optimiser la conception des chaussures pour enfants. Le but de cette étude est de comparer la morphologie du pied des enfants chinois et mongols de 7 à 14 ans. Les données relatives de 339 enfants mongols et de 379 enfants chinois ont été collectées à l'aide d'un scanner 3D pour le pied. Les résultats de cette étude sont les suivants : i) la longueur absolue du pied des enfants chinois est nettement supérieure à celle des enfants mongols du même âge ; ii) les enfants mongols présentent une largeur de talon, une épaisseur des orteils, une hauteur de malléole latérale, une hauteur de cou-de-pied et une circonférence de la région des métatarses sensiblement plus grandes que les enfants chinois du même âge. La largeur du pied des enfants chinois est nettement supérieure à celle des enfants mongols du même âge ; iii) les enfants chinois ont un risque d'hallux valgus plus élevé que les enfants mongols des deux sexes. Les petites variations dans la morphologie du pied discutées dans cet article pourraient être utiles lors de la conception de chaussures pour les enfants mongols et chinois.

MOTS CLÉS : morphologie du pied, enfants mongols, enfants chinois, conception de chaussures

\section{INTRODUCTION}

Knowledge of foot morphology is the most essential requirement to optimize children's footwear design [1]. The foot morphology and motor development of children are changeable with increasing age [2-4]. Studies indicated that there was high variability of foot morphology of children due to difference in region, lifestyle, ethnicity, etc. [5]. Isabel C.N. Sacco et al. [6] found that German children had a wider forefoot ( 5 to 9 years old) and narrower rear foot ( 4 years old) compared to Brazilian children. Kusumoto, A. [7] showed that the protuberance of the first metatarsal phalanx joint was found in $4.5 \%$ of Filipino children, but in none of Japanese children. Mauch, M. et al. [8] found that German children displayed a significantly longer and flatter foot compared to Australian children. Previous literature also reported the significant differences in foot morphology of adults living in different countries $[9,10]$. Therefore, the footwear industry should vary the last dimensions

\footnotetext{
* Correspondence to: Assoc. Prof. Luming YANG, Key Laboratory of Leather Chemistry and Engineering, Sichuan University, No. 24 South Section 1, Yihuan Road, Chengdu, China, 610065, phone: +861862811 7800, e-mail: ylmIl1982@126.com
} 
on the basis of foot morphology when exporting products to different countries [11].

Most children's footwear purchased in Mongolia are designed and manufactured overseas, mainly from China [12]. As previously mentioned, differences in foot morphology may exist among different countries. It is not sure if using Chinese lasts in Mongolian footwear industries can ensure a good fit for Mongolian children shoes [13]. Ill-fitting footwear has been reported to be the major cause for discomfort, pain, and even foot problems [14]. Therefore, the purpose of this study is to investigate the foot morphology between Chinese and Mongolian children from 7 to 14 years through comparative analysis of foot dimensions. The hypothesis put forward is that there are obvious differences in foot morphology between Chinese and Mongolian children.

\section{MATERIALS AND METHODS}

\section{Participants}

Two anthropometric databases were involved. The Mongolian database consists of 339 children aged 7 to 14 years old, who were recruited from Ulan Bator, Mongolia [12]. To match the Mongolian database in terms of age, body height and body mass, 379 healthy Chinese children aged 7 to 14 years in the Chinese database were selected. These Chinese children were recruited from randomly selected primary schools and middle schools in Yantai city, Shandong Province, China. Children who demonstrated a history of neuromuscular disease, orthopedic, lower-limb injury or discomfort during walking were excluded from the study.

The participants were separated into eight age groups at an interval of one year, and every age group was classified by gender. The basic information of all participants is shown in Table 1. The descriptive values are presented as mean (standard deviation). Parents or guardians were informed of children's participation in the study in advance and signed a written informed consent. The study was approved by the Ethics Committee of the Sichuan University.

Table 1: Basic information of participants (mean (standard deviation))

\begin{tabular}{lcccccccccc}
\hline $\begin{array}{c}\text { Age } \\
\text { (yrs) }\end{array}$ & Height & Body mass & BMI & Boys & Girls & Height & Body mass & BMI & Boys & Girls \\
& $(\mathrm{cm})$ & $(\mathrm{kg})$ & $\left(\mathrm{kg} / \mathrm{m}^{2}\right)$ & $(\mathrm{n})$ & $(\mathrm{n})$ & $(\mathrm{cm})$ & $(\mathrm{kg})$ & $\left(\mathrm{kg} / \mathrm{m}^{2}\right)$ & $(\mathrm{n})$ & $(\mathrm{n})$ \\
\hline $7-$ & $126.4(4.8)$ & $25.1(1.8)$ & $16.2(0.6)$ & 19 & 30 & $124.5(2.9)$ & $24.4(2.7)$ & $15.2(1.1)$ & 24 & 15 \\
$8-$ & $131.7(4.2)$ & $30.2(2.0)$ & $17.4(0.2)$ & 49 & 63 & $129.7(4.6)$ & $26.1(3.4)$ & $15.5(1.3)$ & 14 & 15 \\
$9-$ & $137.6(4.8)$ & $34.0(2.1)$ & $18.0(0.5)$ & 24 & 30 & $135.5(4.9)$ & $29.7(3.9)$ & $16.2(1.5)$ & 16 & 15 \\
$10-$ & $144.3(6.3)$ & $39.4(3.8)$ & $18.9(0.7)$ & 15 & 28 & $143.9(6.0)$ & $35.3(5.5)$ & $17.0(1.9)$ & 17 & 16 \\
$11-$ & $151.3(8.1)$ & $45.2(6.0)$ & $19.7(1.1)$ & 15 & 25 & $150.5(7.6)$ & $40.6(7.3)$ & $17.8(2.1)$ & 34 & 27 \\
$12-$ & $157.4(8.4)$ & $48.8(5.8)$ & $19.6(0.7)$ & 19 & 24 & $156.4(7.4)$ & $44.9(6.7)$ & $18.3(2.1)$ & 28 & 21 \\
$13-$ & $163.8(5.8)$ & $53.8(4.7)$ & $20.0(1.0)$ & 9 & 14 & $161.5(5.6)$ & $49.5(6.4)$ & $18.9(1.5)$ & 31 & 14 \\
$14-$ & $164.7(10.6)$ & $55.6(8.1)$ & $20.4(0.6)$ & 5 & 10 & $160.8(9.4)$ & $49.3(9.0)$ & $18.9(1.6)$ & 22 & 30 \\
\hline
\end{tabular}

\section{Procedure}

Foot measurements were obtained with the Infoot foot scanner (IFU-S-01), which was developed by I-Ware Lab, Japan. Eight digital cameras were used to synchronously record the foot measurements. The foot scanner was mounted on a level and smooth ground. After familiarization, each participant was required to stand still with bipedal support and with the body weight evenly distributed on both feet.

\section{Statistical Analysis}

Thirteen foot parameters of foot morphology are shown in Table 2.

All analyses were performed for the right foot [15-18]. Statistical analyses were conducted with SPSS 17.0 (IBM). One-sample Kolmogorov-Smirnov test was tested for all data. Independent t-test was used to compare the significant differences of all normally distributed data between group 1 (Chinese children) and 
group 2 (Mongolian children). Effect size (ES) was calculated as a tool of consistent measure using Cohen's $d$ value. The interpretation of ES was set at trivial (0-0.2), small (0.2-0.6), moderate (0.6-1.2) and large (> 1.2) [19]. Linear regression equation and correlation coefficient
' $r$ ' were calculated. Chi-square test was used to determine the difference of the hallux valgus rate between genders and countries. The level of $p<$ 0.05 was perceived as significance for statistical analyses. 


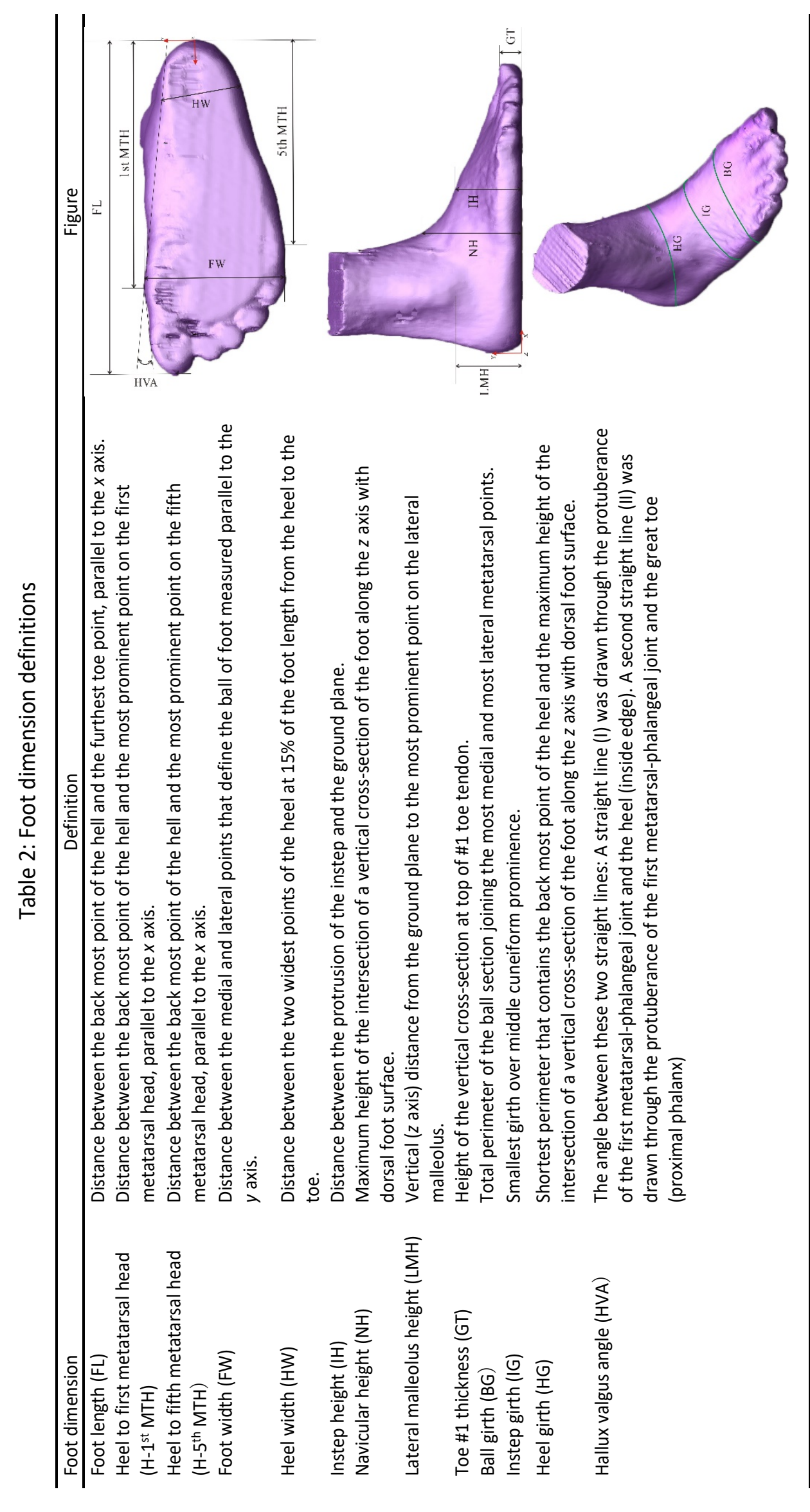


RESULTS

\section{Foot Dimension}

The trend of foot length with age is shown in Figure 1. The foot length of children increased with age in both countries. Measures of absolute foot length of Chinese children were significantly greater than that of Mongolian children at the same age $(p<0.05)$.

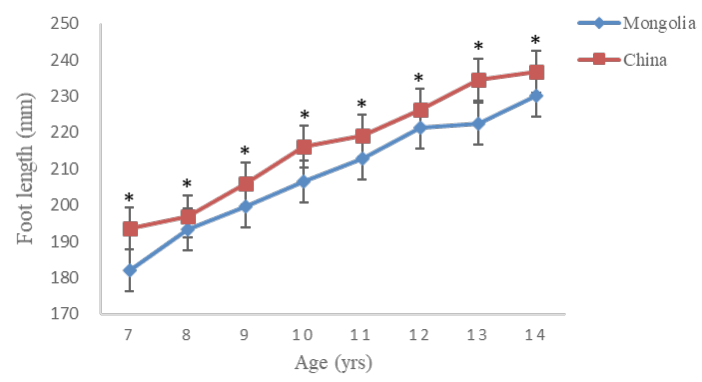

Figure 1. (a): Relationship between foot length and age of boys aged 7-14 years; (b): Relationship between foot length and age of girls aged 7-14 years

Descriptive values of $\mathrm{H}-1^{\text {st }} \mathrm{MTH}$ and $\mathrm{H}-5^{\text {th }}$ MTH are shown in Table 3. Significant differences for $\mathrm{H}-1^{\text {st }}$ MTH and $\mathrm{H}-5^{\text {th }}$ MTH were not found between the two groups. Table 4 shows that the FW of Mongolian children was significantly smaller than that of Chinese children ( 8 to 10 years old). The HW of Mongolian children was significantly greater than that of Chinese children (9 to 10 years old). However, if we analyze the normalized HW, significant differences were found. It showed that the normalized HW of Mongolian children was significantly greater than that of Chinese children ( 7 to 10 years old).
Descriptive values of $\mathrm{GT}, \mathrm{IH}, \mathrm{NH}$ and $\mathrm{LMH}$ are shown in Table 5. Mongolian children showed significantly greater GT and LMH compared to Chinese children for all ages. Chinese children's feet were significantly smaller in $\mathrm{IH}$ than Mongolian children at the age of 7, 8, 9, 11, 12 . Descriptive values of $\mathrm{GT}, \mathrm{IH}, \mathrm{NH}$ and $\mathrm{LMH}$ are shown in Table 6. When BG was normalized to the foot length, significant differences can be found. It showed that the normalized BG of Mongolian children was significantly greater than that of Chinese children at the age of 7, 14. 
Table 3: Mean (SD) values of absolute and normalized foot length dimensions with $p$ values and effect sizes for significant results for the two groups

\begin{tabular}{|c|c|c|c|c|c|c|c|}
\hline \multirow[t]{2}{*}{ Variables } & \multirow{2}{*}{$\begin{array}{l}\text { Age } \\
\text { (yrs) }\end{array}$} & \multicolumn{2}{|c|}{ Absolute (mm) } & \multirow[t]{2}{*}{$p$ value, $\mathrm{ES}^{*}$} & \multicolumn{2}{|c|}{ Normalized (to foot length) } & \multirow[t]{2}{*}{$p$ value, ES* } \\
\hline & & Group 1 & Group 2 & & Group 1 & Group 2 & \\
\hline \multirow[t]{8}{*}{ H-1st MTH } & 7- & $143.68(6.37)$ & $132.63(9.12)$ & 0.44 & $0.73(0.02)$ & $0.72(0.01)$ & 0.42 \\
\hline & 8- & $148.75(6.41)$ & $139.07(11.75)$ & 0.21 & $0.73(0.02)$ & $0.73(0.01)$ & 0.42 \\
\hline & 9- & $153.89(9.49)$ & $147.38(7.01)$ & 0.17 & $0.74(0.02)$ & $0.74(0.02)$ & 0.09 \\
\hline & $10-$ & 162.68(9.71) & $153.82(11.74)$ & 0.10 & $0.75(0.02)$ & $0.74(0.02)$ & 0.11 \\
\hline & 11- & $170.6(7.81)$ & $154.62(8.52)$ & 0.14 & $0.75(0.02)$ & $0.74(0.01)$ & 0.13 \\
\hline & $12-$ & 178.63(9.24) & 167.39(10.63) & 0.31 & $0.75(0.01)$ & $0.74(0.01)$ & 0.42 \\
\hline & $13-$ & $178.93(6.43)$ & 170.03(9.79) & 0.12 & $0.76(0.02)$ & $0.74(0.01)$ & 0.14 \\
\hline & 14- & $188.89(20.67)$ & $177.41(9.83)$ & 0.07 & $0.73(0.02)$ & $0.72(0.01)$ & 0.09 \\
\hline \multirow[t]{8}{*}{ H-5th MTH } & 7- & $126.44(6.18)$ & $115.42(7.64)$ & 0.45 & $0.64(0.01)$ & $0.63(0.02)$ & 0.42 \\
\hline & 8- & $130.41(6.45)$ & $120.14(9.21)$ & 0.39 & $0.64(0.02)$ & $0.63(0.01)$ & 0.43 \\
\hline & 9- & $136.91(6.12)$ & $126.06(6.98)$ & 0.12 & $0.65(0.02)$ & $0.63(0.01)$ & 0.09 \\
\hline & $10-$ & $142.65(8.5)$ & 133.71(9.21) & 0.09 & $0.65(0.02)$ & $0.63(0.02)$ & 0.11 \\
\hline & 11- & $148.01(8.32)$ & $135.82(9.18)$ & 0.07 & $0.65(0.01)$ & $0.64(0.02)$ & 0.09 \\
\hline & $12-$ & $155.69(8.42)$ & $143.36(9.53)$ & 0.23 & $0.65(0.01)$ & $0.64(0.02)$ & 0.13 \\
\hline & 13- & $156.91(7.23)$ & $145.68(8.70)$ & 0.47 & $0.65(0.02)$ & $0.64(0.01)$ & 0.42 \\
\hline & 14- & $164.16(20.6)$ & $153.32(8.05)$ & 0.09 & $0.65(0.02)$ & $0.64(0.01)$ & 0.10 \\
\hline
\end{tabular}

Group 1: Chinese children, Group 2: Mongolian children.

Table 4: Mean (SD) values of absolute and normalized foot width dimensions with $p$ values and effect sizes for significant results for the two groups

\begin{tabular}{|c|c|c|c|c|c|c|c|}
\hline \multirow[t]{2}{*}{ Variables } & \multirow{2}{*}{$\begin{array}{l}\text { Age } \\
\text { (yrs) }\end{array}$} & \multicolumn{2}{|c|}{ Absolute (mm) } & \multirow[t]{2}{*}{$p$ value, $\mathrm{ES}^{*}$} & \multicolumn{2}{|c|}{ Normalized (to foot length) } & \multirow[t]{2}{*}{$p$ value, $\mathrm{ES}^{*}$} \\
\hline & & Group 1 & Group 2 & & Group 1 & Group 2 & \\
\hline \multirow[t]{8}{*}{ FW } & 7- & $75.99(3.82)$ & $67.54(5.54)$ & 0.07 & $0.39(0.02)$ & $0.37(0.01)$ & 0.09 \\
\hline & 8- & 77.94(4.17) & $68.64(5.96)$ & $<0.05,1.80 *$ & $0.39(0.03)$ & $0.36(0.02)$ & $<0.05,1.17^{*}$ \\
\hline & 9- & $80.93(4.93)$ & $72.75(4.14)$ & $<0.05,1.79 *$ & $0.39(0.02)$ & $0.36(0.01)$ & $<0.05,1.89 *$ \\
\hline & $10-$ & $82.92(5.84)$ & $77.29(5.08)$ & $<0.05,1.03 *$ & $0.40(0.03)$ & $0.36(0.01)$ & $<0.05,1.78^{*}$ \\
\hline & $11-$ & $86.11(6.01)$ & $76.56(3.87)$ & 0.09 & $0.38(0.02)$ & $0.36(0.02)$ & 0.10 \\
\hline & $12-$ & $90.83(5.9)$ & $81.04(5.83)$ & 0.43 & $0.38(0.06)$ & $0.36(0.03)$ & 0.63 \\
\hline & $13-$ & $96.26(5.67)$ & $83.03(5.68)$ & 0.11 & $0.38(0.03)$ & $0.36(0.02)$ & 0.09 \\
\hline & 14- & $96.80(2.26)$ & $87.55(7.23)$ & 0.08 & $0.38(0.02)$ & $0.36(0.02)$ & 0.10 \\
\hline \multirow[t]{8}{*}{ HW } & 7- & $47.88(4.09)$ & $48.77(3.55)$ & 0.09 & $0.25(0.02)$ & $0.27(0.02)$ & $<0.05,1.00^{*}$ \\
\hline & 8- & $49.14(3.9)$ & $50.54(3.19)$ & 0.08 & $0.25(0.02)$ & $0.27(0.02)$ & $<0.05,1.00^{*}$ \\
\hline & 9- & $51.05(4.11)$ & $53.07(3.52)$ & $<0.05,0.53^{*}$ & $0.25(0.01)$ & $0.27(0.02)$ & $<0.05,1.26^{*}$ \\
\hline & $10-$ & $53.00(5.03)$ & $55.70(3.82)$ & $<0.05,0.61^{*}$ & $0.25(0.01)$ & $0.27(0.02)$ & $<0.05,1.26^{*}$ \\
\hline & 11- & $55.88(3.62)$ & $57.68(3.50)$ & 0.27 & $0.25(0.02)$ & $0.26(0.01)$ & 0.42 \\
\hline & $12-$ & $59.86(5.10)$ & $61.42(4.43)$ & 0.18 & $0.25(0.01)$ & $0.26(0.02)$ & 0.42 \\
\hline & 13- & $60.74(7.16)$ & $62.00(4.60)$ & 0.12 & $0.25(0.01)$ & $0.26(0.01)$ & 0.28 \\
\hline & 14- & $63.50(6.05)$ & $65.06(4.33)$ & 0.09 & $0.25(0.01)$ & $0.26(0.02)$ & 0.24 \\
\hline
\end{tabular}

Group 1: Chinese children, Group 2: Mongolian children.

${ }^{*} p$ represents significant difference between Group 1 and Group 2 
Table 5: Mean (SD) values of absolute and normalized foot height dimensions with $p$ values and effect sizes for significant results for the two groups

\begin{tabular}{|c|c|c|c|c|c|c|c|}
\hline \multirow[t]{2}{*}{ Variables } & \multirow{2}{*}{$\begin{array}{l}\text { Age } \\
\text { (yrs) }\end{array}$} & \multicolumn{2}{|c|}{ Absolute (mm) } & \multirow[t]{2}{*}{$p$ value, $\mathrm{ES}^{*}$} & \multicolumn{2}{|c|}{ Normalized (to foot length) } & \multirow[t]{2}{*}{$p$ value, ES* } \\
\hline & & Group 1 & Group 2 & & Group 1 & Group 2 & \\
\hline \multirow[t]{8}{*}{ GT } & 7- & $14.64(1.46)$ & $25.71(3.34)$ & $<0.01,4.29 *$ & $0.07(0.01)$ & $0.14(0.02)$ & $<0.01,4.42 *$ \\
\hline & 8- & $15.89(1.70)$ & $26.57(3.28)$ & $<0.01,4.08^{*}$ & $0.08(0.02)$ & $0.14(0.01)$ & $<0.01,3.78^{*}$ \\
\hline & 9- & $15.9(1.52)$ & $28.13(2.16)$ & $<0.01,6.54^{*}$ & $0.08(0.02)$ & $0.14(0.01)$ & $<0.01,3.00 *$ \\
\hline & $10-$ & $16.78(1.35)$ & $29.35(2.76)$ & $<0.01,5.78^{*}$ & $0.08(0.01)$ & $0.14(0.02)$ & $<0.01,3.79 *$ \\
\hline & $11-$ & $17.28(1.24)$ & $29.38(2.23)$ & $<0.01,6.70^{*}$ & $0.08(0.02)$ & $0.14(0.01)$ & $<0.01,3.79 *$ \\
\hline & $12-$ & $17.69(1.44)$ & $30.64(2.70)$ & $<0.01,5.98^{*}$ & $0.07(0.01)$ & $0.14(0.02)$ & $<0.01,4.42 *$ \\
\hline & 13- & $19.14(2.34)$ & $31.87(1.69)$ & $<0.01,6.23^{*}$ & $0.08(0.02)$ & $0.14(0.03)$ & $<0.01,2.35^{*}$ \\
\hline & $14-$ & $19.44(2.85)$ & $32.77(2.16)$ & $<0.01,5.27^{*}$ & $0.08(0.01)$ & $0.14(0.02)$ & $<0.01,3.79 *$ \\
\hline \multirow[t]{8}{*}{$\mathrm{IH}$} & 7- & 43.09(5.60) & $51.42(3.35)$ & $<0.05,1.80 *$ & $0.22(0.02)$ & $0.27(0.02)$ & $<0.05,2.50 *$ \\
\hline & 8- & $45.13(4.85)$ & $53.21(4.02)$ & $<0.05,1.81^{*}$ & $0.22(0.02)$ & $0.27(0.02)$ & $<0.05,2.50 *$ \\
\hline & 9- & 47.90(4.95) & $53.81(2.79)$ & $<0.05,1.47^{*}$ & $0.23(0.02)$ & $0.27(0.02)$ & $<0.05,2.00 *$ \\
\hline & $10-$ & $53.18(5.16)$ & $56.41(3.64)$ & 0.11 & $0.24(0.02)$ & $0.27(0.02)$ & 0.09 \\
\hline & $11-$ & $53.49(6.94)$ & $58.53(3.99)$ & $<0.05,0.89 *$ & $0.24(0.02)$ & $0.28(0.02)$ & $<0.05,2.00 *$ \\
\hline & $12-$ & $55.10(6.38)$ & 59.79(3.69) & $<0.05,0.90^{*}$ & $0.25(0.02)$ & $0.28(0.02)$ & $<0.05,1.50 *$ \\
\hline & $13-$ & $64.22(4.77)$ & $60.32(3.89)$ & 0.15 & $0.26(0.02)$ & $0.28(0.01)$ & 0.10 \\
\hline & $14-$ & $67.45(4.74)$ & $62.00(5.23)$ & 0.06 & $0.26(0.02)$ & $0.28(0.02)$ & 0.09 \\
\hline \multirow[t]{8}{*}{$\mathrm{NH}$} & 7- & $60.37(3.90)$ & $65.96(4.92)$ & 0.09 & $0.31(0.02)$ & $0.33(0.02)$ & 0.06 \\
\hline & 8- & 61.53(3.91) & $67.21(4.95)$ & 0.07 & $0.31(0.02)$ & $0.33(0.03)$ & 0.11 \\
\hline & 9- & 64.41(3.72) & 69.81(5.59) & 0.09 & $0.31(0.02)$ & $0.33(0.02)$ & 0.09 \\
\hline & $10-$ & $68.86(5.73)$ & $71.88(3.43)$ & 0.13 & $0.32(0.02)$ & $0.34(0.02)$ & 0.31 \\
\hline & $11-$ & 71.79(4.09) & 74.97(5.15) & 0.09 & $0.32(0.02)$ & $0.34(0.03)$ & 0.15 \\
\hline & $12-$ & $76.49(5.06)$ & $77.68(4.36)$ & 0.17 & $0.32(0.01)$ & $0.34(0.02)$ & 0.09 \\
\hline & $13-$ & $79.06(4.58)$ & $78.61(4.58)$ & 0.21 & $0.32(0.01)$ & $0.34(0.01)$ & 0.10 \\
\hline & $14-$ & $81.18(5.27)$ & $80.41(8.29)$ & 0.37 & $0.32(0.02)$ & $0.34(0.02)$ & 0.30 \\
\hline \multirow[t]{8}{*}{$\mathrm{LMH}$} & 7- & $35.76(5.09)$ & $50.46(5.12)$ & $<0.01,2.88^{*}$ & $0.18(0.01)$ & $0.28(0.02)$ & $<0.01,6.32 *$ \\
\hline & 8- & $38.49(3.44)$ & $51.79(6.33)$ & $<0.01,2.61^{*}$ & $0.19(0.02)$ & $0.27(0.01)$ & $<0.01,5.06^{*}$ \\
\hline & 9- & $40.88(5.21)$ & $52.94(4.20)$ & $<0.01,2.54^{*}$ & $0.19(0.02)$ & $0.27(0.02)$ & $<0.01,4.00^{*}$ \\
\hline & $10-$ & $45.52(5.95)$ & $58.88(3.30)$ & $<0.01,2.62^{*}$ & $0.22(0.02)$ & $0.28(0.02)$ & $<0.01,3.00^{*}$ \\
\hline & $11-$ & $45.71(4.82)$ & $59.53(5.67)$ & $<0.01,2.75^{*}$ & $0.21(0.02)$ & $0.28(0.03)$ & $<0.01,2.75^{*}$ \\
\hline & $12-$ & $50.36(5.50)$ & $60.75(4.32)$ & $<0.01,2.06^{*}$ & $0.21(0.02)$ & $0.27(0.01)$ & $<0.01,3.79 *$ \\
\hline & $13-$ & $54.40(3.75)$ & $62.45(5.48)$ & $<0.01,1.71 *$ & $0.22(0.01)$ & $0.27(0.02)$ & $<0.01,3.16^{*}$ \\
\hline & $14-$ & $56.53(4.46)$ & $66.05(6.97)$ & $<0.01,1.63^{*}$ & $0.22(0.01)$ & $0.27(0.03)$ & $<0.01,2.23^{*}$ \\
\hline
\end{tabular}

Group 1: Chinese children, Group 2: Mongolian children.

${ }^{*} p$ represents significant difference between Group 1 and Group 2 
Table 6: Mean (SD) values of absolute and normalized foot breadth dimensions with $p$ values and effect sizes for significant results for the two groups

\begin{tabular}{|c|c|c|c|c|c|c|c|}
\hline \multirow[t]{2}{*}{ Variables } & \multirow{2}{*}{$\begin{array}{l}\text { Age } \\
\text { (yrs) }\end{array}$} & \multicolumn{2}{|c|}{ Absolute (mm) } & \multirow[t]{2}{*}{$p$ value, $\mathrm{ES}^{*}$} & \multicolumn{2}{|c|}{ Normalized (to foot length) } & \multirow[t]{2}{*}{$p$ value, ES* } \\
\hline & & Group 1 & Group 2 & & Group 1 & Group 2 & \\
\hline \multirow[t]{8}{*}{ BG } & 7- & 190.19(11.63) & $184.58(13.28)$ & 0.06 & $0.97(0.01)$ & $0.99(0.02)$ & $<0.05,1.26^{*}$ \\
\hline & 8- & $197.25(10.32)$ & $190.43(14.85)$ & 0.09 & $0.97(0.02)$ & $0.99(0.02)$ & 0.15 \\
\hline & 9- & 205.65(10.83) & 195.69(9.53) & 0.43 & $0.97(0.03)$ & $0.99(0.02)$ & 0.33 \\
\hline & 10- & $208.54(5.84)$ & $208.18(12.57)$ & 0.83 & $0.96(0.06)$ & $0.99(0.04)$ & 0.59 \\
\hline & 11- & 216.85(14.82) & $205.32(11.01)$ & 0.47 & $0.94(0.02)$ & $0.96(0.03)$ & 0.31 \\
\hline & $12-$ & 227.03(13.09) & 217.5(14.29) & 0.09 & $0.95(0.02)$ & $0.96(0.02)$ & 0.29 \\
\hline & 13- & 238.65(12.15) & 222.74(13.07) & 0.07 & $0.96(0.01)$ & $0.97(0.02)$ & 0.42 \\
\hline & 14- & $242.15(4.94)$ & 235.41(16.06) & 0.10 & $0.94(0.02)$ & $0.96(0.03)$ & $<0.05,0.78^{*}$ \\
\hline \multirow[t]{8}{*}{ IG } & 7- & 199.53(12.00) & $185.42(11.56)$ & 0.37 & $1.02(0.03)$ & $1.01(0.03)$ & 0.59 \\
\hline & 8- & 202.54(19.7) & $192.00(13.39)$ & 0.51 & $1.00(0.02)$ & $0.99(0.04)$ & 0.83 \\
\hline & 9- & $206.86(11.85)$ & $197.00(9.08)$ & 0.43 & $0.99(0.03)$ & $0.98(0.02)$ & 0.09 \\
\hline & 10- & $203.01(12.31)$ & 207.18(11.07) & 0.81 & $0.96(0.05)$ & $0.96(0.04)$ & 0.91 \\
\hline & $11-$ & $224.31(18.67)$ & $206.71(9.54)$ & 0.23 & $0.97(0.05)$ & $0.96(0.03)$ & 0.76 \\
\hline & $12-$ & 219.8(22.39) & $216.68(15.48)$ & 0.75 & $0.93(0.04)$ & $0.95(0.02)$ & 0.42 \\
\hline & 13- & 241.55(15.15) & $222.97(14.48)$ & 0.11 & $0.98(0.02)$ & $0.96(0.01)$ & 0.33 \\
\hline & 14- & $252.41(5.05)$ & $235.55(14.76)$ & 0.21 & $0.96(0.04)$ & $0.96(0.02)$ & 0.83 \\
\hline \multirow[t]{8}{*}{ HG } & 7- & $263.46(17.25)$ & $243.92(12.8)$ & 0.23 & $1.32(0.05)$ & $1.34(0.03)$ & 0.42 \\
\hline & 8- & $269.45(34.51)$ & $254.5(15.82)$ & 0.51 & $1.34(0.03)$ & $1.33(0.02)$ & 0.55 \\
\hline & 9- & $272.72(14.18)$ & $264.00(12.21)$ & 0.43 & $1.30(0.03)$ & $1.33(0.03)$ & 0.10 \\
\hline & $10-$ & $277.71(30.56)$ & $280.82(15.08)$ & 0.79 & $1.32(0.07)$ & $1.31(0.05)$ & 0.81 \\
\hline & $11-$ & $300.33(38.96)$ & $280.53(11.53)$ & 0.11 & $1.28(0.07)$ & $1.31(0.03)$ & 0.61 \\
\hline & $12-$ & $304.95(28.28)$ & $296.57(18.50)$ & 0.83 & $1.28(0.03)$ & $1.30(0.03)$ & 0.18 \\
\hline & $13-$ & $311.22(16.28)$ & $301.65(16.07)$ & 0.41 & $1.27(0.01)$ & $1.31(0.03)$ & 0.30 \\
\hline & $14-$ & $328.13(17.18)$ & 317.95(19.19) & 0.37 & $1.25(0.04)$ & $1.29(0.02)$ & 0.18 \\
\hline
\end{tabular}

Group 1: Chinese children, Group 2: Mongolian children.

${ }^{*} p$ represents significant difference between Group 1 and Group 2

\section{Correlation of Foot Parameters}

The foot length and ball girth are considered to be the main functional foot parameters for shoe fitting [20]. Linear regression analysis was used to identify the relationship between foot length and ball girth for both genders. The regression results are shown in Figure 3 as follows:

(1) For Chinese boys: Ball girth =

(0.847 $x$ foot length) $+39.85, r^{2}=0.717$;

(2) For Chinese girls: Ball girth $=$

(0.859 $x$ foot length) $+26.91, r^{2}=0.738$;
(3) For Mongolian boys: Ball girth =

(0.791 $x$ foot length) $+39.11, r^{2}=0.802$;

(4) For Mongolian girls: Ball girth $=(0.768 x$ foot length) $+31.26, r^{2}=0.794$. 


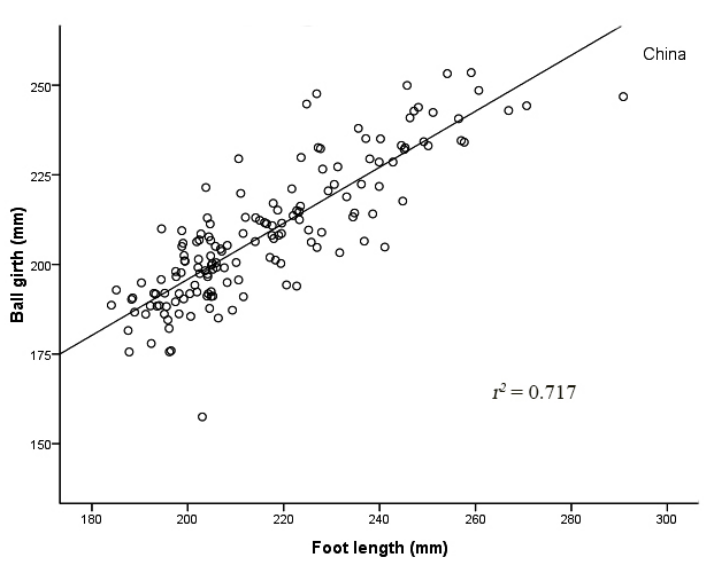

a)

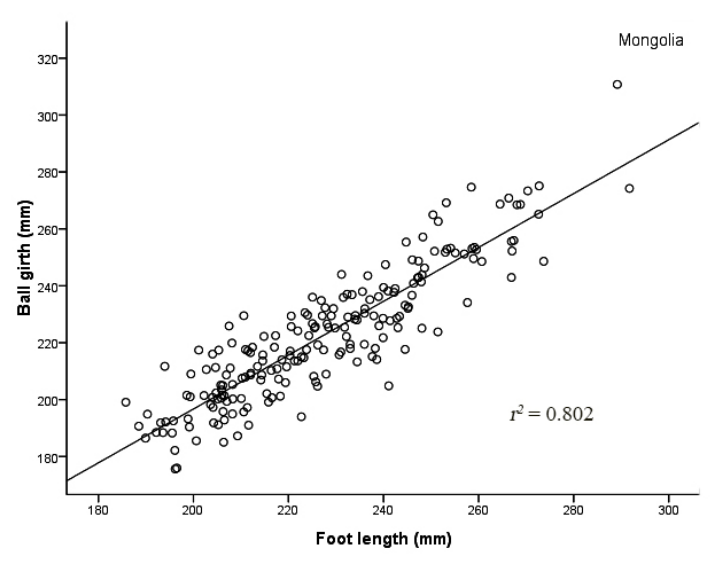

c)

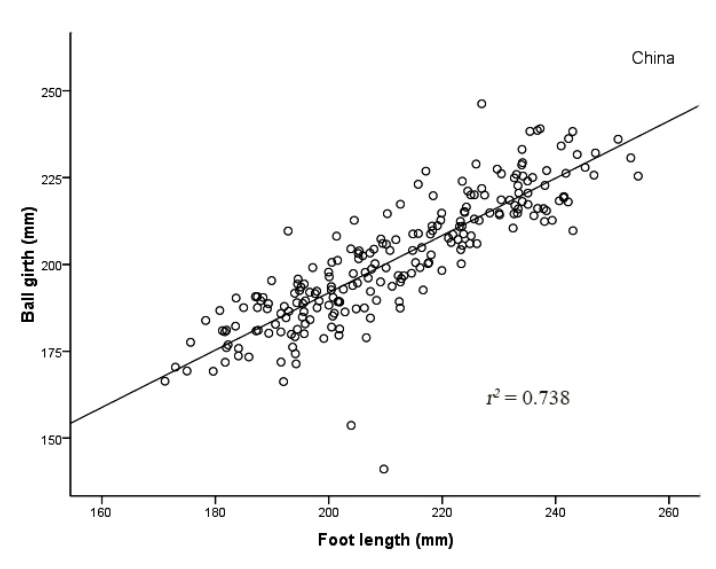

a)

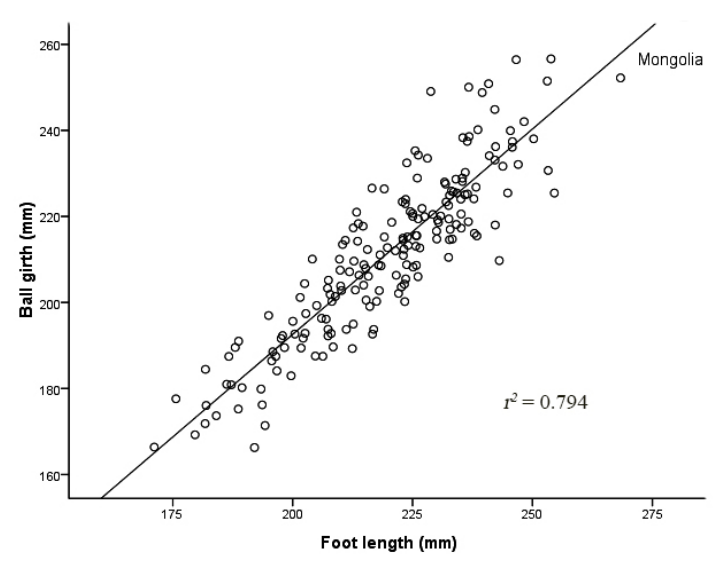

d)

Figure 3. Correlation between foot length and ball girth for both genders, by countries.

(a): Chinese boys; (b): Chinese girls; (c): Mongolian boys; (d): Mongolian girls

\section{Hallux Valgus}

Measures of absolute hallux valgus angles are shown in Table 7. It was observed that hallux valgus angles of Chinese children were significantly greater than those of Mongolian children $(p<0.05)$. The degrees of hallux valgus were divided into three grades in Table 8: "Straight or mild", "Moderate" and "Severe" [12]. Chi-square test was used to determine the difference of the hallux valgus rate between genders and countries. The results showed that Chinese children appeared to demonstrate higher incidences of hallux valgus compared to Mongolian children of both sexes (for boys: $x^{2}=10.97, p=0.004$; for girls: $x^{2}=14.48, p=$ 0.001 , respectively). Results revealed that girls appeared to demonstrate higher incidences of hallux valgus compared with boys in both countries for all ages (for China: $x^{2}=12.90$, $p=0.002$; for Mongolia: $x^{2}=10.68, p=0.005$, respectively).

Table 7: Comparison of means (standard deviations) of hallux valgus of the Chinese and Mongolian populations

\begin{tabular}{ccccc}
\hline Foot dimension & \multicolumn{2}{c}{ Boys } & \multicolumn{2}{c}{ Girls } \\
& China & Mongolia & China & Mongolia \\
\hline Hallux valgus angles $\left({ }^{\circ}\right)$ & $8.16(4.49)$ & $6.05(3.21)$ & $10.04(4.53)$ & $7.31(3.05)$ \\
\hline
\end{tabular}


Table 8: The number and proportion of participants with hallux valgus

\begin{tabular}{ccccc}
\hline \multirow{2}{*}{ Classification of hallux valgus } & \multicolumn{2}{c}{ Girls, $\mathrm{n}(\%)$} & \multicolumn{2}{c}{ Boys, $\mathrm{n}(\%)$} \\
& China & Mongolia & China & Mongolia \\
\hline Straight or mild $\left(>-10^{\circ}\right.$ and $\left.<+10^{\circ}\right)$ & $128(57.15 \%)$ & $112(73.20 \%)$ & $114(73.55 \%)$ & $162(87.10 \%)$ \\
Moderate $\left(>+11^{\circ}\right.$ and $\left.<+15^{\circ}\right)$ & $67(29.91 \%)$ & $36(23.53 \%)$ & $34(21.93 \%)$ & $22(11.82 \%)$ \\
Severe $\left(>+16^{\circ}\right)$ & $29(12.95 \%)$ & $5(3.27 \%)$ & $7(4.52 \%)$ & $2(1.08 \%)$ \\
Total & 224 & 153 & 155 & 186 \\
\hline
\end{tabular}

\section{DISCUSSION}

The results of this study showed that the foot length of Chinese children was significantly greater than that of Mongolian children of the same age. Studies have already shown the significant association between body height, body mass and foot length [21-23]. To match the Mongolian database, the Chinese database was controlled for age, body height and body mass as variable factors. But the tendency of higher height and body mass of Chinese children could be a reason for the difference in foot length. Previous study assumed that the differences in daily diet (especially protein intake) may be related to the differences in children' growth [6].

In comparison to the Chinese children, Mongolian children showed significantly greater toe thickness, instep height and lateral malleolus height. It implies that the vamp designed for Mongolian children should be of sufficient depth. Results showed that the foot width of Chinese children is significantly greater than that of Mongolian children. It indicates that the vamp designed for Chinese children should allow sufficient space around the metatarsal joint area, in order not to damage the soft cartilaginous toes or toe nails [18]. In this study, the absolute foot width of the Chinese children was similar to that of the Filipino children in Kusumoto's study [7], while Chinese children had a larger foot length compared to Filipino children. It is postulated that not only differences in dietary habit, but also differences in ethnicities and region may be responsible for modifying the shape of foot. The normalized foot dimensions provide the necessary information for describing the foot characteristics [24]. Interestingly, when the foot measures were normalized to the length of the foot, significantly greater ball girth and heel width were found in Mongolian children.

The most common foot deformity known and irregularity treated is hallux valgus, which affects more than $35 \%$ of individuals [25]. The results obtained in our study showed that girls appeared to demonstrate higher rates of moderate hallux valgus compared to boys of the same age in both countries, which have been proved in early literature [26]. However, Chinese children could be at a higher risk for hallux valgus compared to Mongolian children. Results showed that $30.11 \%$ of Chinese girls and $22.3 \%$ of Chinese boys aged from 7 to 14 years had hallux valgus deformity (greater than $8^{\circ}$ ). But the exact prevalence rate of hallux valgus is difficult to determine because of the paucity of large-scale epidemiological studies and varying definitions used in the literature. There is no unified explanation of what angle represents a healthy or deformed foot in the big toe area. Some authors indicated $8^{\circ}$, others used $10^{\circ}$, or $15^{\circ}[25$ 29]. Specifically, hallux valgus found in different populations proved to be related to poorly-fitting footwear $[25,28,29]$. The prevalence of hallux valgus is higher in Chinese children, mainly due to the habit of wearing shoes with a narrow toe box. Because shoe styles for children tend to follow the fashion trends for adults, more so in regards to shape rather than the comfort [4]. Therefore, the footwear industry should vary the last dimensions on the basis of foot morphology when exporting products to specific countries.

\section{CONCLUSION}

In comparison to the Mongolian children, Chinese children had significantly greater foot length and foot width. However, Mongolian children showed significantly greater toe thickness, instep height, lateral malleolus height, heel width and ball girth than those of Chinese children. The hypothesis is proved that there is obvious difference in foot morphology between Chinese children and Mongolian children. This study thus suggests that small variations in foot 
morphology should be considered in the shoe design for specific children. It is hoped that prospective studies could measure more foot parameters, like Chippaux-Smirak and Staheli indices of the longitudinal arch, which are also important variables for the footwear industry.

\section{Conflict of Interest}

There were no conflicts of interest with other authors or institution for this study.

\section{Acknowledgments}

This research was supported by the National Natural Science Foundation of China [grant number: 11502154]. The authors would express sincere gratitude to all the experimenters and participants who made this study possible.

\section{REFERENCES}

1. Noviani, A.D., Widyanti, A., Integrating Anthropometry Approach and Kansei Engineering in the Design of Children Shoe, Leather and Footwear Journal, 2018, 18, 4, 295-306, https://doi.org/10.24264/Ifj.18.4.5.

2. Martinez-Nova, A., Gijon-Nogueron, G., Alfageme-Garcia, P., Montes-Alguacil, J., Evans, A.M., Foot posture development in children aged 5 to11 years: A three-year prospective study, Gait Posture, 2018, 62, 280-4, https://doi.org/10.1016/j. gaitpost.2018.03.032.

3. Feng, Y., Xu, B., Zhou, J., Effects of the stride length on the gait and intra-limbs coordination of healthy children aged 3 to 6, Leather and Footwear Journal, 2019, 19, 1, 3-10, https:// doi.org/10.24264/Ifj.19.1.1.

4. Xu, M., Wang, L., Foot growth and foot types in children and adolescents: a narrative review, Sheng Wu Yi Xue Gong Cheng Xue Za Zhi, 2017, 34, 648-52.

5. Shariff, S.M., Merican, A.F., Shariff, A.A., Foot morphological between ethnic groups, Anthropometry, Apparel Sizing and Design, 2020, 317-30, https://doi.org/10.1016/B9780-08-102604-5.00012-3.

6. Sacco, I.C., Onodera, A.N., Bosch, K., Rosenbaum, D., Comparisons of foot anthropometry and plantar arch indices between German and Brazilian children, BMC
Pediatr, 2015, 15, 4, https://doi.org/10.1186/ s12887-015-0321-z.

7. Kusumoto, A., Comparative foot dimensions in Filipino rural children and Tokyo children, Ann Hum Biol, 1990, 17, 249- 55, https://doi. org/10.1080/03014469000001022.

8. Mauch, M., Mickle, K.J., Munro, B.J., Dowling, A.M.,Grau,S.,Steele,J.R., DothefeetofGerman and Australian children differ in structure? Implications for children's shoe design, Ergonomics, 2008, 51, 4, 527-39, https://doi. org/10.1080/00140130701660520.

9. Gurney, J.K., Kersting, U.G., Rosenbaum, D., Dynamic foot function and morphology in elite rugby league athletes of different ethnicity, Ergonomics, 2009, 40, 554-9, https://doi. org/10.1016/j.apergo.2008.11.001.

10. Ashizawa, K., Kumakura, C., Kusumoto, A., Relative foot size and shape to general body size in Javanese, Filipinas and Japanese with special reference to habitual footwear types, Ann Hum Biol, 1997, 24, 117-29, https://doi. org/10.1080/03014469700004862.

11. Hawes, M.R., Sovak, D., Miyashita, M., Kang, S.J., Yoshihuku, Y., Tanaka, S., Ethnic differences in forefoot shape and the determination of shoe comfort, Ergonomics, 1994, 37, 187-96, https://doi. org/10.1080/00140139408963637.

12. Batbaatar, T., The influence of the origin of country on consumer intentions - An empirical investigation into reviews on Mongolian consumers: East China Normal University, 2015.

13. Yanjia, Y., The impact of China's direct investment in Mongolia on Sino-Mongolian Trade and Its Countermeasures, Beijing Jiaotong University, 2017.

14. Aiyer, A., Hennrikus, W., Foot pain in the child and adolescent, Pediatr Clin North Am, 2014, 61, 1185-205, https://doi.org/10.1016/j. pcl.2014.08.005.

15. Menz, H.B., Two feet, or one person? Problems associated with statistical analysis of paired data in foot and ankle medicine, The Foot, 2004, 14, 2-5, https://doi.org/10.1016/ S0958-2592(03)00047-6.

16. Manna, I., Pradhan, D., Ghosh, S., Kar, S.K., Dhara, P., A Comparative Study of Foot Dimension between Adult Male and Female and Evaluation of Foot Hazards due to Using 
of Footwear, J Physiol Anthropol Appl Human Sci, 2001, 20, 241-6, https://doi.org/10.2114/ jpa.20.241.

17. Leung, L.A.K., Cheng, J.C.Y., Mak, A.F.T., A cross-sectional study on the development of foot arch function of 2715 Chinese children, Prosthet Orthot Int, 2005, 29, 241-53, https:// doi.org/10.1080/03093640500199695.

18. Mauch, M., Grau, S., Krauss, I., Maiwald, C., Horstmann, T., A new approach to children's footwear based on foot type classification, Ergonomics, 2009, 52, 999-1008, https://doi. org/10.1080/00140130902803549.

19. A New View of Statistics, http://www. sportsci.org/resource/stats/, 2016.

20. Furong, H., Meiling, R., Shiyang, Y., Luming, Y., Research on Foot Shape and Plantar Pressure Distribution of Contemporary Chinese Young Women, Leather Science and Engineering, 2013, 23, 47-51.

21. Yousefi Azarfam, A.A., Ozdemir, O., Altuntas, O., Cetin, A., Gokce Kutsal, Y., The relationship between body mass index and footprint parameters in older people, Foot (Edinb), 2014, 24, 186-9, https://doi.org/10.1016/j. foot.2014.08.009.

22. Price, C., Nester, C., Foot dimensions and morphology in healthy weight, overweight and obese males, Clin Biomech (Bristol, Avon), 2016, 37, 125-30, https://doi.org/10.1016/j. clinbiomech.2016.07.003.

23. Kouchi, M., Foot dimension and foot shape: Different due to growth, generation and ethic origin, Anthropol Sci, 1998, 106, 161-88, https://doi.org/10.1537/ase.106. Supplement_161.
24. Delgado-Abellán, L., Aguado, X., JiménezOrmeño, E., Mecerreyes, L., Alegre, L.M., Foot morphology in Spanish school children according to sex and age, Ergonomics, 2014, 57, 787-97, https://doi.org/10.1080/001401 39.2014.895055.

25. Robinson, C., Bhosale, A., Pillai, A., Footwear modification following hallux valgus surgery: The all-or-none phenomenon, World J Methodol, 2016, 6, https://doi.org/10.5662/ wjm.v6.i2.171.

26. Nishimura, A., Kato, K., Fukuda, A., Prevalence of hallux valgus and risk factors among Japanese community dwellers, J Orthop Sci, 2013, 19, 257-62, https://doi.org/10.1007/ s00776-013-0513-z.

27. Hao, G., Zhicheng, S., Recent advances in $X$ ray observation index of hallux valgus and their applications, China J Orthop Trauma, 2013, 26, 171-4.

28. Barnett, C.H., The normal orientation of the human hallux and the effect of footwear, $J$ Anat, 1962, 96, 94-489.

29. Shine, B.L., Incidence of Hallux Valgus in a Partially Shoe-wearing Community, $\mathrm{Br}$ Med J, 1965, 1648-50, https://doi.org/10.1136/ bmj.1.5451.1648.

(C) 2020 by the author(s). Published by INCDTPICPI, Bucharest, RO. This is an open access article distributed under the terms and conditions of the Creative Commons Attribution license (http:// creativecommons.org/licenses/by/4.0/). 